\title{
A 973 valine to methionine mutation of the human insulin receptor: interaction with insulin-receptor substrate-1 and Shc in HEK 293 cells
}

\author{
V. Strack ${ }^{1}$, B. B ossenmaier ${ }^{2}$, B . Stoyanov ${ }^{1}$, J. M ushack ${ }^{1}$, H . U . H äring ${ }^{1}$ \\ ${ }^{1}$ Eberhard-Karls-Universität Tübingen, Innere Medizin IV, Tübingen, Germany \\ ${ }^{2}$ Boehringer Mannheim GmbH, Molekularbiologie, Mannheim, Germany
}

Summary A population-based study in the Netherlands has recently demonstrated that a mutation of the human insulin receptor (HIR-973 valine to methionine) is associated with hyperglycaemia and an increased prevalence of non-insulin-dependent diabetes mellitus (NIDDM). The aim of the present study was to assess whether this mutation leads to a functional alteration of the insulin receptor. We prepared the HIR-973 mutant by in vitro mutagenesis. This mutant was transiently overexpressed in HEK 293 cells either alone or together with insulin-receptor substrate-1 (IRS-1) or Shc. Insulin stimulated autophosphorylation, phosphorylation of the substrates IRS-1 and Shc as well as activation of phosphatidylinositol-3 (PI3)-kinase were studied. Autophosphorylation of HIR-973 and its susceptibility to hyperglycaemia induced inhibition was not different from HIR-wt. Human insulin receptor with a juxtamembrane deletion HIR- $\Delta \mathrm{JM}$ which is known to impair HIR/IRS-1 interaction was used as control. While the HIR- $\Delta$ JM induces a reduced IRS-1 phosphorylation HIR-973 showed even a slightly increased ability to phosphorylate IRS-1 ( $\mathrm{n}=7,115 \%$ of control, $p<0.01$ ). Shc phosphorylation was only mediated by HIR-wt and HIR-973 but not by HIR- $\Delta$ JM.
Again a tendency to higher phosphorylation of Shc was seen with HIR-973 ( $n=7,109 \%$ of control, NS). When PI3-kinase activity was measured in IRS-1 precipitates similar activity was found for HIR-wt and HIR-973 whereas PI3-kinase stimulation was reduced with HIR- $\Delta \mathrm{JM}$. In summary, the data suggest that HIR-973 does not impair the first steps of the insulin signalling cascade. It is therefore unlikely that this mutation may cause cellular insulin resistance. The close vicinity of this mutation to insulin receptor domains which are involved in IRS-1 and Shc binding may, however, alter the interaction of the insulin receptor with these substrates. This could explain the slightly increased insulin effect on tyrosine phosphorylation of these docking proteins. These characteristics of HIR-973 might have a compensatory function of impaired signal transduction further downstream of the signalling chain in this specific subgroup of NIDDM patients. [Diabetologia (1997) 40: 1135-1140]

Keywords NIDDM, insulin receptor, mutation, hyperglycaemia, substrate phosphorylation, PI3-kinase.
Received: 29 January 1997 and in final revised form: 18 June 1997

Corresponding author: Professor Dr. H.-U. Häring, Abt. Innere Medizin IV, Otfried-Müller-Str. 10, D-72 076 Tübingen, Germany

A bbreviations: NIDDM, Non-insulin-dependent-diabetes mellitus; HEK, human embryonic kidney; HIR, human insulin receptor; HIR- $\triangle \mathrm{JM}, \mathrm{HIR}$ with juxtamembrane deletion; wt, wild-type; FCS, fetal calf serum; PI3-kinase, phosphatidylinositol-3'-kinase; PIP, phosphatidylinositol-3'-phosphate; OGTT, oral glucose tolerance test; Hepes; N-2-hydroxyethylpiperazine-N-2-ethanesulphonic acid; PMSF, phenylmethylsulfonyl fluoride; TLC, thin layer chromatography; ECL, enhanced chemoluminescence; PBS, phosphate buffered saline; Ptyr, phosphorylated tyrosine residues. 
Insulin resistance plays a central role in the pathogenesis of non-insulin-dependent diabetes mellitus (NIDDM) [1, 2]. It is believed that both primary genetically determined factors as well as secondary events related to lifestyle, development of obesity as well as metabolic derangements contribute through different molecular mechanisms to the impairment of insulin signalling which causes insulin resistance $[3,4]$. Multiple studies have investigated whether structural abnormalities of the insulin receptor might contribute to the primary causes of insulin resistance. A number of different insulin receptor mutations were described which cause syndromes of extreme insulin resistance $[5,6]$. In contrast to these rare syndromes common forms of NIDDM seem to be very rarely associated $(<1 \%)$ with insulin receptor mutations [7]. A clearly higher prevalence of an insulin receptor mutation in an NIDDM population was recently described by Maassen et al. [8, 9]. These authors examined 161 individuals with NIDDM and 538 healthy control subjects in a population-based study for the presence of mutations in the insulin receptor gene. In $5.6 \%$ of the diabetic subjects these authors found a heterozygous mutation changing valine 973 (985 in numbering for HIR-B i.e. HIR exon11 +) into methionine whereas individuals with a normal oral glucose tolerance test (OGTT) have a prevalence of $1.3 \%$. Furthermore, the authors described that the prevalence of this mutation is associated with the degree of hyperglycaemia. Elbein's group [10] have provided some evidence that within pedigrees the Met-973 insulin receptor variant associates with elevated post load glucose levels. Initially, this mutation of the human insulin receptor was described in an insulin resistant patient with lipodystrophy [11] and was expressed in chinese hamster ovary (CHO) cells. No major abnormality in insulin induced receptor autophosphorylation was found [6] suggesting that insulin resistance in individuals bearing this mutation is probably not due to an impaired receptor activation. However, position 973 is located in the juxtamembrane region of the insulin receptor which is an important structural domain for receptor internalization and for the interaction of the insulin receptor with the substrates insulin-receptor substrate-1 (IRS-1) and Shc [12-14]. Therefore, a modulation of signalling events which are downstream of the insulin receptor autophosphorylation seems conceivable. The amino acid motive around the tyrosine residue at position $960\left(\mathrm{NPEY}^{960}\right)$ determines the interaction of the insulin receptor with the signalling proteins IRS-1 and Shc [15-18]. Due to the close vicinity of valine 973 to tyrosine 960 it seems possible that this mutation might modulate the interaction of insulin receptor with IRS-1 or Shc. This might cause an altered activation of IRS-1 and PI3-kinase which are both involved in insulin induced activation of glucose transport [19-21] as well as signalling to glycogen synthase
$[22,23]$. An impairment of these signalling steps might therefore be relevant for the pathogenesis of insulin resistance [24]. The aim of our study was therefore to characterize the mutated receptor HIR973 in HEK 293 cells due to its autophosphorylation and susceptibility to hyperglycaemia induced inhibition. Furthermore we examined the interaction of HIR-973 with IRS-1, Shc and PI3-kinase activity.

\section{Materials and methods}

M aterials. Cell culture reagents and fetal calf serum (FCS) were purchased from Gibco (Eggenstein, Germany); culture dishes were from Greiner (Frickenhausen, Germany). Porcine insulin, aprotinin, phenylmethylsulfonyl fluoride (PMSF), $\mathrm{Na}_{3} \mathrm{VO}_{4}$, Triton $\mathrm{X}-100$, and dithiothreitol were from Sigma (Munich, Germany). The reagents for SDS-PAGE and Western blotting were obtained from Roth (Karlsruhe, Germany) and Biorad (Munich, Germany). Nitrocellulose was from Schleicher \& Schuell (Dassel, Germany). All other reagents were of the best grade commercially available. Visualization of immunocomplexes after Western blotting was performed with the non-radioactive enhanced chemiluminescence system (ECL) and the Hyperfilm-ECL from Amersham Buchler (Braunschweig, Germany). [ $\left.\gamma^{32} \mathrm{P}\right] \mathrm{ATP}$ was from NEN-DuPont (Bad Homburg, Germany).

The cDNA for the wild-type receptor (HIR-wt) or the insulin receptor with a juxtamembrane deletion (HIR- $\Delta \mathrm{JM}$ ) and the polyclonal rabbit antibody against insulin receptor $\beta$-subunit (CT104/anti- $\beta$-subunit) were gifts from Dr. Axel Ullrich (Max-Planck-Institute, Martinsried, Germany). The cDNAs for the IRS-1 and Shc were kindly provided by Dr. Morris F. White (Joslin Diabetes Center, Boston, Mass., USA) as well as the polyclonal rabbit antibody against IRS-1. The monoclonal mouse antibody against phosphorylated tyrosine residues (anti-Ptyr) were from Leinco Technologie Inc. (Ballwin, MO, USA), the polyclonal rabbit antibodies against Shc were from Upstate Biotechnology Inc. (Lake Placid, N. J., USA).

Transient expression of HIR-wt, HIR- $\Delta$ JM and HIR-973 in HEK 293 cells. The cDNA for the wild-type insulin receptor or the insulin receptor with a juxtamembrane deletion (amino acids 954-965) and the 973 valine to methionine mutation were cloned into a cytomegalovirus promoter-based expression vector [25] and plasmid DNA was prepared using a Qiagen Plasmid Kit. HEK 293 cells (ATCC CRL 1573) were grown in Dulbecco's modified Eagle's medium/Nutrient Mix F12 medium supplemented with $10 \%$ FCS. A total of $4 \mu \mathrm{g}$ plasmid DNA was transfected per semiconfluent 35-mm diameter dish according to the protocol of Chen and Okayama [26]. Cultures were maintained overnight at $37^{\circ} \mathrm{C}, 3 \% \mathrm{CO}_{2}$.

The medium was changed at $20 \mathrm{~h}$ before experiment to a minimum essential medium (1000 mg/l glucose) without FCS containing $2 \mathrm{mmol} / \mathrm{l}$ glutamine. Cells were then preincubated with or without $25 \mathrm{mmol} / 1$ 2-deoxyglucose for $30 \mathrm{~min}$ before stimulation with indicated insulin concentrations at $37^{\circ} \mathrm{C}$ for $5 \mathrm{~min}$. Subsequently cells were lysed in $200 \mu \mathrm{l}$ lysis buffer (50 mmol/l Hepes pH 7.2, $150 \mathrm{mmol} / \mathrm{l} \mathrm{NaCl}, 1 \mathrm{mmol} / \mathrm{l}$ EGTA, $10 \%$ (v/v) glycerol, $1 \%$ (v/v) Triton X-100, $100 \mathrm{mmol} / \mathrm{l} \mathrm{NaF}$, $10 \mathrm{mmol} / 1$ sodium pyrophosphate, $100 \mu \mathrm{mol} / 1$ sodium orthovanadate, $1 \mathrm{mmol} / \mathrm{l} \mathrm{PMSF}, 10 \mu \mathrm{g} / \mathrm{ml}$ aprotinin). The lysates were centrifuged for $10 \mathrm{~min}$ at $14000 \mathrm{~g}, 40 \mu \mathrm{l}$ of the supernatant was taken, $5 \times$ Laemmli buffer added [27], boiled for $5 \mathrm{~min}$, and separated by $7.5 \%$ SDS-PAGE. 
Western blotting. Denatured proteins were separated by SDSPAGE and transferred to nitrocellulose by electroblotting (transfer buffers: 1) $300 \mathrm{mmol} / \mathrm{l}$ Tris $\mathrm{pH} 10.4,20 \%$ methanol; 2) $25 \mathrm{mmol} / \mathrm{l}$ Tris $\mathrm{pH} 10.4,20 \%$ methanol; 3) $25 \mathrm{mmol} / \mathrm{l}$ Tris pH 9.4, $20 \%$ methanol, $40 \mathrm{mmol} / \mathrm{l}$ amino-n-capronacid). After transfer, the membranes were blocked with NET buffer ( $150 \mathrm{mmol} / \mathrm{l} \mathrm{NaCl}, 5 \mathrm{mmol} / \mathrm{l}$ EDTA, $50 \mathrm{mmol} / \mathrm{l}$ Tris, $0.05 \%$ Triton $\mathrm{X}-100$ and $0.25 \%$ gelatine, $\mathrm{pH} 7.4)$ for $1 \mathrm{~h}$. Subsequently they were incubated with the first antibody (for anti- $\beta$-subunit (CT104) in phosphate buffered saline (PBS) with 2\% dried milk and $0.2 \%$ gelatine, for all other antibodies in NET buffer) overnight at $4^{\circ} \mathrm{C}$. The nitrocellulose membranes were washed $4 \times 10$ min with NET buffer before incubating with horseradish peroxidase-conjugated anti-rabbit IgG or anti-mouse $\mathrm{IgG}$ for $1 \mathrm{~h}$ at room temperature. Visualization of immunocomplexes was performed by ECL.

P hosphatidylinositol-3-kinase assay. PI3-kinase activity was determined as described [28-30]. Briefly, confluent cells were incubated with or without $10^{-7} \mathrm{~mol} / 1$ insulin for $5 \mathrm{~min}$ at $37^{\circ} \mathrm{C}$ and lysed at $4{ }^{\circ} \mathrm{C}$ in buffer A containing $1 \%(\mathrm{v} / \mathrm{v})$ Nonidet P$40,10 \%$ (v/v) glycerol, $20 \mathrm{mmol} / \mathrm{l}$ Tris- $\mathrm{HCl}(\mathrm{pH}$ 7.5), $137 \mathrm{mmol} / \mathrm{l} \mathrm{NaCl}, 1 \mathrm{mmol} / \mathrm{l} \mathrm{MgCl}, 1 \mathrm{mmol} / 1 \mathrm{CaCl}_{2}, 2 \mathrm{mmol} / \mathrm{l}$ PMSF and $100 \mu \mathrm{mol} / 1$ sodium orthovanadate. Lysates were centrifuged at $16000 \mathrm{~g}$ for $20 \mathrm{~min}$ and supernatants were incubated overnight with antibodies (anti-IRS-1) and protein-ASepharose. Immunoprecipitates were washed twice with PBS, $1 \%$ (v/v) Nonidet P-40, $100 \mu \mathrm{mol} / \mathrm{l}$ sodium orthovanadate; twice with $500 \mathrm{mmol} / \mathrm{l} \mathrm{LiCl}, 100 \mathrm{mmol} / \mathrm{l}$ Tris-HCl (pH 7.5), $100 \mu \mathrm{mol} / \mathrm{l}$ sodium orthovanadate; and twice with $10 \mathrm{mmol} / \mathrm{l}$ Tris- $\mathrm{HCl}(\mathrm{pH}$ 7.5), $100 \mathrm{mmol} / \mathrm{l} \mathrm{NaCl}, 1 \mathrm{mmol} / \mathrm{l}$ EDTA, $100 \mu \mathrm{mol} / \mathrm{l}$ sodium orthovanadate. The pellets were resuspended in $25 \mu \mathrm{l}$ of $60 \mathrm{mmol} / \mathrm{l}$ Tris- $\mathrm{HCl}$ ( $\mathrm{pH} \mathrm{7.4),} 300 \mathrm{mmol} / \mathrm{l} \mathrm{NaCl}$, $12 \mathrm{mmol} / \mathrm{l} \mathrm{MgCl}_{2}$ and $12.5 \mu \mathrm{l}$ phosphatidylinositol $(1 \mathrm{mg} / \mathrm{ml})$. The kinase reaction was initiated by adding $12.5 \mu \mathrm{l}$ of $40 \mu \mathrm{mol} / \mathrm{l}$ ATP containing $10 \mu \mathrm{Ci}\left[\gamma^{32} \mathrm{P}\right] \mathrm{ATP}$ at room temperature. Exactly 15 min later the reaction was terminated with $20 \mu l 8 \mathrm{~N}$ $\mathrm{HCl}$ and $160 \mu \mathrm{l}$ chloroform:methanol (1:1). The organic phase containing phospholipids was lyophilized, subsequently dissolved in $10 \mu \mathrm{l}$ chloroform:methanol (1:1) and separated on a silica gel thin layer chromatography (TLC) plate coated with chloroform:methanol:water:ammonia $=60: 47$ : 11.3:2 (by volume). ${ }^{32} \mathrm{P}$-labelled spots were detected by autoradiography.

\section{Results}

Figure 1 shows the insulin induced receptor autophosphorylation in HEK 293 cells transfected with HIR-wt, HIR- $\triangle$ JM and HIR-973. Western blots with antibodies against the insulin receptor $\beta$-subunit were used to monitor insulin receptor expression. Anti-phosphotyrosine antibodies were applied to detect insulin stimulated receptor autophosphorylation. No significant differences in insulin induced tyrosine autophosphorylation were observed for HIR-wt and HIR-973 while a clearly reduced insulin receptor autophosphorylation was observed with HIR- $\Delta \mathrm{JM}$. Furthermore we examined whether the mutation 973 Val $\rightarrow$ Met might exhibit an altered susceptibility to hyperglycaemia induced inhibitory mechanisms. We have earlier shown that hyperglycaemia induces inhibition of insulin receptor kinase of HIR-wt [31]. Figure 1 shows that the inhibitory effect of acute

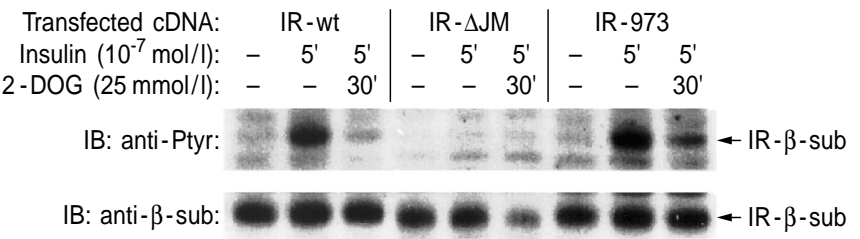

Fig. 1. Insulin-induced receptor autophosphorylation and the effect of 2-deoxyglucose. Whole cell lysates were prepared from HEK 293 fibroblast. Cells overexpressing the wild-type receptor or the mutant receptors (IR- $\Delta$ JM, IR-973) were incubated with $25 \mathrm{mmol} / 1$ 2-deoxyglucose (2-DOG) for $30 \mathrm{~min}$ and subsequently stimulated with $10^{-7} \mathrm{~mol} / 1$ insulin at $37^{\circ} \mathrm{C}$ for $5 \mathrm{~min}$. Proteins were separated by SDS-PAGE; Western blots were probed with antibodies against phosphotyrosine residues (anti-Ptyr) or insulin receptor (anti- $\beta$-sub), respectively. A representative immunoblot is shown. These results were reproduced in six different experiments

hyperglycaemia (25 mmol/l deoxyglucose) was observed in all receptor preparations.

To test whether HIR-973 might differ with respect to insulin sensitivity compared to wild type we performed dose response curves. Figure 2 a shows a representative autoradiogram of insulin dose response, the mean values of five experiments quantified by scanning densitometry are shown as Figure $2 \mathrm{~b}$. We could not observe any significant differences between HIR-973 and HIR-wt.

To study the interaction of the different insulin receptor constructs with IRS-1 the cells were co-transfected both with cDNA of HIR and IRS-1. Figure 3 shows in the upper part a representative Western blot with anti-Ptyr antibodies to detect insulin receptor and IRS-1 phosphorylation. In the lower part of the figure Western blots are shown with antibodies against IRS- 1 respectively insulin receptor $\beta$-subunit to quantify the expression levels of insulin receptor and its substrate IRS-1. Due to the high expression level of IRS-1 significant tyrosine phosphorylation is found in the absence of insulin. If IRS-1 is co-expressed with HIR- $\triangle \mathrm{JM}$ a clearly reduced tyrosine phosphorylation of IRS-1 is observed. This confirms earlier data which have demonstrated that the juxtamembrane region is relevant for the interaction between the insulin receptor and IRS-1. With HIR-973 the impairment of IRS-1 phosphorylation is not observed, in contrast an even slightly increased phosphorylation of IRS-1 after insulin stimulation was found. We used scanning densitometry to quantify the degree of tyrosine phosphorylation. The quantification of seven independent experiments revealed that the degree of tyrosine phosphorylation of IRS-1 co-transfected with HIR-973 caused an approximately $15 \%(p<0.01)$ increase of IRS-1 phosphorylation. Experiments where the cell lysates were immunoprecipitated with anti-IRS-1 antibodies and then reblotted with anti-Ptyr antibodies and anti-IRS-1 (data not shown) confirm the result from Figure 3 


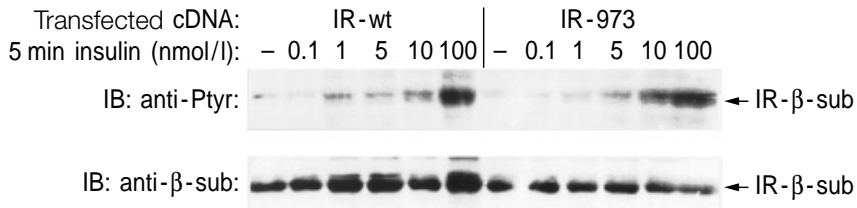

a

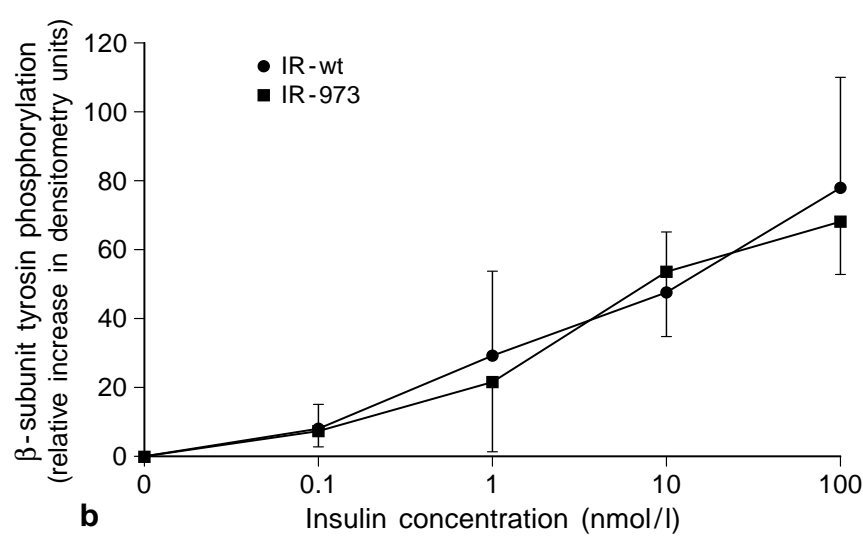

Fig. 2. The effect of different insulin concentrations to the receptor autophosphorylation. Whole cell lysates were prepared from HEK 293 fibroblast. Cells overexpressing the wild-type receptor or the mutant receptors (IR- $\Delta J M$, IR-973) were stimulated with the indicated insulin concentrations at $37^{\circ} \mathrm{C}$ for 5 min. Proteins were separated by SDS-PAGE; Western blots were probed with antibodies against phosphotyrosine residues (anti-Ptyr) or insulin receptor (anti- $\beta$-sub), respectively. a) A representative immunoblot. b) The densitometric analysis of five independent experiments. The relative increase in densitometry units is shown

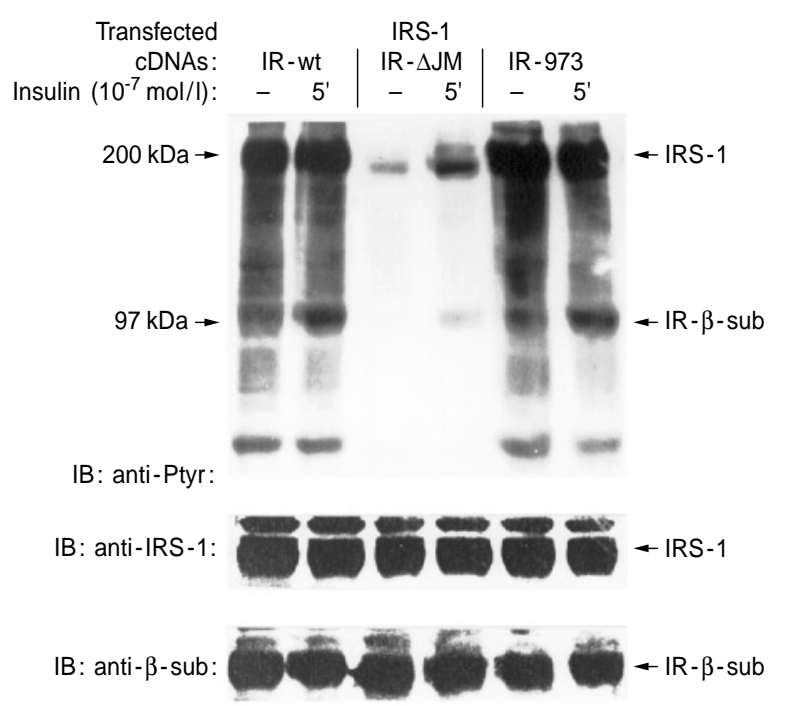

Fig. 3. Co-expression of IRS-1 and the different insulin receptors. Whole cell lysates were prepared from HEK 293 fibroblast. Cells overexpressing the IRS-1 and the different insulin receptors (IR-wt, IR- $\Delta$ JM or IR-973, respectively) were stimulated with $10^{-7} \mathrm{~mol} / \mathrm{l}$ insulin at $37^{\circ} \mathrm{C}$ for $5 \mathrm{~min}$. Proteins were separated by SDS-PAGE; Western blots were probed with antibodies against phosphotyrosine residues (anti-Ptyr), IRS-1 (anti-IRS-1) or insulin receptor (anti- $\beta$-sub), respectively. A representative immunoblot is shown. The result was reproduced in seven independent experiments demonstrating that IRS-1 phosphorylation was not significantly impaired by HIR-973 while only traces of tyrosine phosphorylation are detected in IRS-1 co-transfected with HIR- $\Delta \mathrm{JM}$.

To investigate whether the HIR-973 receptor has an influence on the signalling to the PI3-kinase we assayed the endogenous PI3-kinase activity upon insulin stimulation. Figure 4 shows a representative autoradiography of the separated lipids. The marked spots show the level of phosphatidylinositol-3'-phosphate (PIP) due to the $\left[{ }^{32} \mathrm{P}\right]$ phosphate incorporation into phosphatidylinositol. No difference in insulin-stimulated PI3-kinase activity was observed for HIR-wt or the mutant HIR-973 receptor. In contrast a clearly reduced PI3-kinase activity was detected for HIR- $\Delta$ JM.

In order to examine the interaction of the adapter molecule Shc with the different insulin receptor constructs we overexpressed Shc and HIR-wt or the mutant constructs in HEK 293 cells. Figure 5 shows in the upper part a representative Western blot with anti-Ptyr antibodies to detect insulin receptor and Shc phosphorylation. In the lower part of the figure Western blots are shown with antibodies against Shc respectively insulin receptor $\beta$-subunit to quantify the expression levels of insulin receptor and Shc. No significant differences in the Shc tyrosine phosphorylation level were observed after co-transfection of Shc with HIR-wt or HIR-973, while the tyrosine phosphorylation level of Shc was decreased after coexpression of Shc with HIR- $\Delta \mathrm{JM}$. The quantification of seven separate experiments revealed that the degree of tyrosine phosphorylation of Shc co-transfected with HIR-973 caused a slight $(9 \%$, NS) increase of Shc phosphorylation upon insulin stimulation (data not shown).

\section{Discussion}

The high prevalence of the HIR-973 mutation described by Maassen et al. [8,9] in an NIDDM population suggested the possibility that an impaired signalling function of this receptor mutation might be the cause of insulin resistance in this subgroup of NIDDM individuals. Our present findings do not support this hypothesis. In agreement with earlier studies in a different cell type [6] a normal ability of the insulin receptor to undergo insulin stimulated autophosphorylation on tyrosine residues was found. Furthermore, we did not observe a different susceptibility to hyperglycaemia induced inhibition. It is clear that a normal autophosphorylation of the receptor does not exclude the possibility that subsequent steps of the insulin receptor dependent signalling cascade, i.e. the interaction with IRS-1 and Shc as well as the activation of PI3-kinase might be altered. We have recently described an example for this situation with an insulin receptor bearing a serine to alanine 


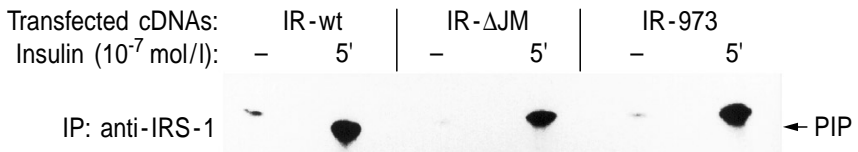

Fig. 4. PI3-kinase activity in anti-IRS-1 immunoprecipitates from insulin-stimulated cells. HEK 293 fibroblast overexpressing different insulin receptors (IR-wt, IR- $\Delta \mathrm{JM}$ or IR-973, respectively) were incubated in the absence or presence of $10^{-7}$ $\mathrm{mol} / \mathrm{l}$ insulin for $5 \mathrm{~min}$ at $37^{\circ} \mathrm{C}$, solubilized and incubated at $4^{\circ} \mathrm{C}$ with anti-IRS-1 antibody and protein-A-Sepharose. PI3Kinase activity in the washed immunoprecipitates was assayed as described, and lipids were extracted and separated by TLC in $\mathrm{CHCl}_{3}: \mathrm{CH}_{3} \mathrm{OH}: \mathrm{H}_{2} \mathrm{O}: \mathrm{NH}_{4} \mathrm{OH} \quad(60: 47: 11.3: 2)$. $\left[{ }^{32} \mathrm{P}\right]$ phosphate incorporation into phosphatidylinositol was visualized by autoradiography after separation of the labelled lipids on TLC plates. The results were obtained in five independent experiments. (PIP: phosphatidylinositol-3'-phosphate)

mutation at positions $1177 / 78 / 82$ in the tyrosine kinase domain. This receptor is still able to undergo normal insulin dependent autophosphorylation while the interaction with IRS-1 is severely altered [32]. We studied the HIR/IRS-1 interaction in a cell system which allows the transient co-expression of insulin receptors and IRS-1 in high concentrations. Due to the fact that both insulin receptors as well as IRS- 1 are expressed in high concentrations we observed elevated basal levels of tyrosine phosphorylation of both IRS-1 and Shc. In such an expression system subtle functional differences which alter the affinity of the insulin receptor to IRS-1 might be overlooked while functional alterations which severely impair HIR and IRS-1 interaction as it was earlier described for the insulin receptor with the $\Delta \mathrm{JM}$ deletion can clearly be demonstrated. The HIR- $\Delta$ JM shows in this system a drastically reduced ability to induce IRS-1 phosphorylation and an impaired ability to stimulate PI3kinase. It is, however, important to note that this receptor construct is also partially able to activate the IRS-1/PI3-kinase signalling chain in this cell system. The observation that this receptor construct does not show the total inability to activate IRS-1 as was earlier described in other cell models $[13,17,32]$ is most likely explained by the high expression levels of both insulin receptors and IRS-1. This may partially compensate for the reduced ability of the HIR- $\Delta \mathrm{JM}$ to interact with IRS-1. In contrast to HIR- $\Delta$ JM the HIR973 is fully able to induce IRS-1 phosphorylation and activate PI3-kinase. The same result is obtained for the ability of the respective receptor constructs to induce phosphorylation of Shc. These data suggest that HIR-973, despite the close vicinity of this mutation to the domain in the juxtamembrane region which is relevant for the coupling of IRS- 1 and Shc to the receptor, does not cause an impairment of this crucial signalling step which follows insulin receptor autophosphorylation. When phosphorylation of both IRS1 and Shc was quantified by scanning densitometry a

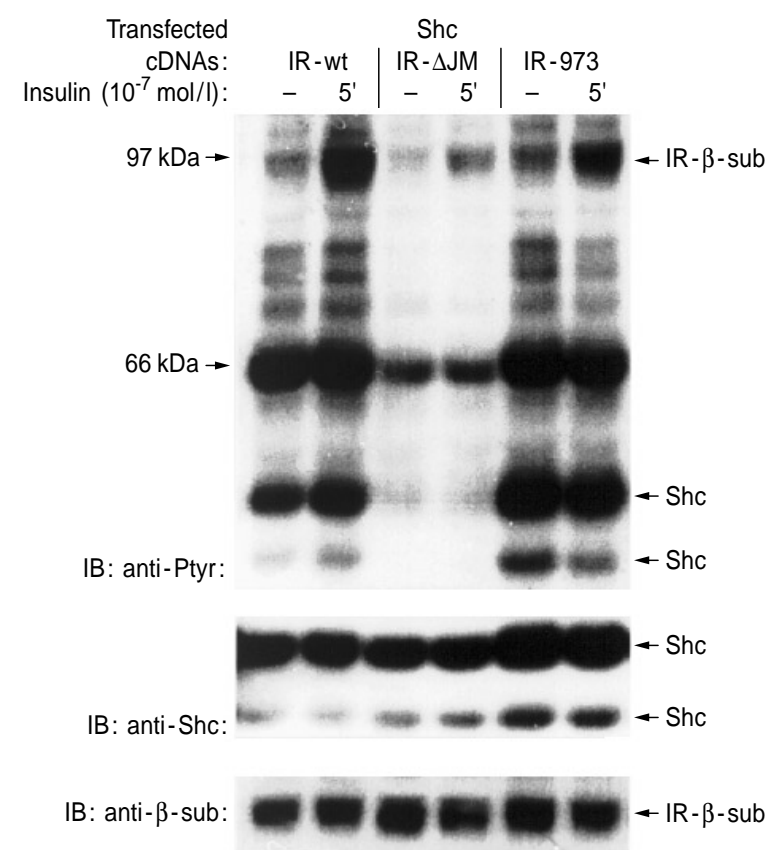

Fig. 5. Co-expression of Shc and the different insulin receptors. Whole cell lysates were prepared from HEK 293 fibroblasts. Cells overexpressing Shc and the different insulin receptors (IR-wt, IR- $\Delta \mathrm{JM}$ or IR-973, respectively) were stimulated with $10^{-7} \mathrm{~mol} / 1$ insulin at $37^{\circ} \mathrm{C}$ for $5 \mathrm{~min}$. Proteins were separated by SDS-PAGE; Western blots were probed with antibodies against phosphotyrosine residues (anti-Ptyr), Shc (anti$\mathrm{Shc}$ ) or insulin receptor (anti- $\beta$-sub), respectively. A representative immunoblot is shown. The same result was reproduced in seven separate experiments

small increase of IRS-1 and Shc phosphorylation was consistently found. It is completely unclear whether this difference might be of any functional significance. If this would be the case one could speculate that the higher prevalence of this receptor mutant in an insulin resistant population would be a compensatory event for a defect in the insulin signalling chain at another level. Analogous observations were described earlier for other elements of the insulin signalling chain, i. e. the relative upregulation of the receptor isoform HIR-B, the glycogen synthase or the rad protein in subgroups of NIDDM individuals [3436].

\section{References}

1. DeFronzo RA, Bonadonna R, Ferrannini E (1992) Pathogenesis of NIDDM. Diabetes Care 15: 318-368

2. Eriksson J, Franssila-Kallunki A, Ekstrand A (1989) Early metabolic defects in persons at increased risk for non-insulin-dependent diabetes mellitus. New Engl J Med 321: 337343

3. Beck-Nielsen H, Groop L (1988) Metabolic and genetic characterization of prediabetic states. Sequence of events leading to non-insulin-dependent diabetes mellitus. J Clin Invest 94: 1714-1721 
4. Häring HU (1991) The insulin receptor: signalling mechanism and contribution to the pathogenesis of insulin resistance. Diabetologia 34: 848-861

5. Taylor SI (1992) Lilly Lecture: molecular mechanism of insulin resistance. Lessons from patients with mutations in the insulin-receptor gene. Diabetes 41: 1473-1490

6. Flier JS, Moller DE, Moses AC et al. (1993) Insulin mediated pseudoacromegaly: clinical and biochemical characterization of a syndrome of insulin resistance. J Clin Endocrinol Metab 76: 1533-1541

7. O'Rahilly S, Krook A, Morgan R, Rees A, Flier JS, Moller DE (1992) Insulin receptor and insulin-responsive glucose transporter (GLUT 4) mutations and polymorphisms in a Welsh type 2 (non-insulin-dependent) diabetic population. Diabetologia 35: 486-489

8. Maassen JA, Hart LM, Heine RJ et al. (1995) An increased frequency of the Met985 insulin receptor variant in patients with type II diabetes mellitus in the Netherlands. Diabetologia 38: A 77 [Suppl] (Abstract)

9. Hart LM, Stolk RP, Heine RJ, Grobbee DE, van der Does FEE, Maassen JA (1996) Association of the insulin receptor variant Met-985 with hyperglycaemia and non- insulindependent diabetes mellitus in the Netherlands: A population-based study. Am J Hum Genet 59: 1119-1125

10. Elbein SC, Sorensen LK, Schumacher C (1993) Methionine for valine substitution in exon 17 of the insulin receptor gene in a pedigree with familial NIDDM. Diabetes 42: 429-434

11. O'Rahilly S, Choi WH, Patel P, Turner RC, Flier JS, Moller DE (1991) Detection of mutations in insulin-receptor gene in NIDDM patients by analysis of single-stranded conformation polymorphisms. Diabetes 40: 777-782

12. Backer JM, Kahn CR, Cahill DA, Ullrich A, White MF (1990) Receptor-mediated internalization of insulin receptor requires a 12-amino acid sequence in the juxtamembrane region of the insulin receptor $\beta$-subunit. $\mathrm{J}$ Biol Chem 265: 16450-16454

13. Kaburagi Y, Momomura K, Yamamoto-Honda R et al. (1993) Site-directed mutagenesis of the juxtamembrane domain of the human insulin receptor. J Biol Chem 268: 16610-16622

14. White MF, Kahn CR (1994) The insulin signalling system. J Biol Chem 269: 1-4

15. He W, O'Neill TJ, Gustafson TA (1995) Distinct modes of interaction of Shc and insulin receptor substrate-1 with the insulin receptor NPEY region via non-SH2 domains. J Biol Chem 270: 23258-23262

16. Kaburagi Y, Yamamoto-Honda R, Tobe K et al. (1995) The role of the NPXY motif in the insulin receptor in tyrosine phosphorylation of insulin receptor substrate-1 and Shc. Endocrinol 136: 3437-3443

17. White MF, Livingston JN, Backer JM, Lauris V, Dull TJ, Ullrich A, Kahn CR (1988) Mutation of the insulin receptor at tyrosine 960 inhibits signal transmission but does not affect its tyrosine kinase activity. Cell 54: 641-649

18. Myers MG Jr, Sun XJ, White MF (1994) The IRS-1 signalling system. Trends Biochem Sci 19: 289-293

19. Kanai F, Ito K, Todaka M et al. (1993) Insulin-stimulated Glut 4 translocation is relevant to the phosphorylation of IRS-1 and the activity of phosphatidylinositol 3-kinase. Biochem Biophys Res Comm 195: 762-768
20. Kotani K, Carozzi AJ, Sakaue H et al. (1995) Requirement for phosphatidylinositol 3-kinase in insulin-stimulated GLUT-4 translocation in 3T3-L1 adipocytes. Biochem Biophys Res Commun 209: 343-348

21. Okada T, Kawano Y, Sakakibara T, Hazeki O, Ui M (1994) Essential role of phosphatidylinositol 3-kinase in insulininduced glucose transport and antilipolysis in rat adipocytes. J Biol Chem 269: 3568-3573

22. Damsbo P, Vaag A, Hother-Nielsen O, Beck-Nielsen H (1990) Reduced glycogen synthase activity in skeletal muscle from obese patients with and without type 2 (non-insulin-dependent) diabetes mellitus. Diabetologia 34: 239-245

23. Beck-Nielsen H, Vaag A, Damsbo P et al. (1992) Insulin resistance in skeletal muscle in patients with NIDDM. Diabetes Care 15: 418-429

24. Häring HU, Mehnert H (1993) Pathogenesis of type 2 (noninsulin-dependent) diabetes mellitus: candidates for a signal transmitter defect causing insulin resistance of skeletal muscle. Diabetologia 36: 176-182

25. Gorman CM, Gies D, McGray G, Huang M (1989) The human cytomegalovirus major immediate early promotor can be trans-activated by adenovirus early proteins. Virology 171: 377-385

26. Chen C, Okayama H (1987) High-effeciency transformation of mammalian cells by plasmid DNA. Mol Cell Biol 7: $2745-2752$

27. Lämmli UK (1970) Cleavage of structural proteins during the assembly of the head of bacteriophage T4. Nature 227: 680-685

28. Auger KR, Serunian LA, Soltoff SP, Libby P, Cantley LC (1989) PDGF-dependent tyrosine phosphorylation stimulates production of novel phosphoinositides in intact cells. Cell 57: 167-175

29. Backer JM, Myers MGJr, Shoelson Seet al. (1992) Phosphatidylinositol 3-kinase is activated by association with IRS-1 during insulin stimulation. EMBO J 11: 3469-3479

30. Ruderman NB, Kapeller R, White MF, Cantley LC (1990) Activation of phosphoinositol 3-kinase by insulin. Proc Nat Acad Sci USA 87: 1411-1415

31. Berti L, Mosthaf L, Kroder G et al. (1994) Glucose-induced translocation of protein kinase C isoforms in Rat-1 fibroblasts is paralleled by inhibition of the insulin receptor tyrosine kinase. J Biol Chem 269: 3381-3386

32. Bossenmaier B, Strack V, Stoyanov B, Mushack J, Häring HU (1996) Human insulin receptor (HIR)/IRS-1 interaction: Serines 1177/78/82 contribute to a second domain required for IRS-1 phosphorylation. Exp Clin Endocrinol Diabetes 104: 18-19 [Suppl] (Abstract)

33. Sun XJ, Miralpeix M, Myers MG Jr et al. (1992) Expression and function of IRS- 1 in insulin signal transmission. J Biol Chem 267(31):22662-22672

34. Kellerer M, Sesti G, Seffer Eet al. (1993) Altered pattern of insulin receptor isotypes in skeletal muscle membranes of type 2 (non-insulin-dependent) diabetic subjects. Diabetologia 36: 628-632

35. Lofman M, Yki-Jarvinen H, Parkkonen M et al. (1995) Increased concentrations of glycogen synthase protein in skeletal muscle of patients with NIDDM. Am J Physiol 269 (1 Pt 1):E27-E32

36. Reynet C, Kahn CR (1993) Rad: a member of the Ras family overexpressed in muscle of type II diabetic humans. Science 262: 1441-1444 